ROCZNIKI HUMANISTYCZNE

Tom LXIX, zeszyt $1-2021$

DOI: https://doi.org/10.18290/rh21691-3

ARENT VAN NIEUKERKEN

\author{
NORWID, KOLEBKA ARIÓW \\ A EUROPA JAKO WIELOKULTUROWE „PRINCIPIUM”
}

\begin{abstract}
1
W norwidologii często zwracano uwagę na ścisłą relację między poezją i prozą artystyczną autora Vade-mecum a jego listami. Można podać wiele przykładów wierszy przedstawiających w poetyckim zagęszczeniu koncepcje i motywy, które wcześniej wystąpiły w korespondencji Norwida. Zdarza się też, że fragmenty z listów komentują (a czasami modyfikują) wcześniejsze wypowiedzi artystyczne. Epistolografia poety zawdzięcza swoje znaczenie m.in. temu, że pozwala do pewnego stopnia zrekonstruować jego lektury, które były rozległe, choć prawdopodobnie nie zawsze systematyczne. Odtwarzanie tych kontekstów jest istotne dla zarysowania Norwidowskiego światopoglądu, na który składa się paradoksalna mieszanka „postępowych” koncepcji pozytywistycznych i „tradycyjnych” pojęć i obrazów katolickich. Właśnie owa różnorodność intelektualnych natchnień stanowi o specyfice Norwidowskiej twórczości. Można ją umieścić w rozmaitych konfiguracjach historycznoliterackich, ale po głębszej analizie okazuje się, że przekracza ona granice między współczesnymi poecie nurtami i prądami. Nawet jeżeli spełnia kilka reguł pewnego paradygmatu stylistycznego, narusza inne jego właściwości. Norwid nie był późnym romantykiem ani poetyckim przedstawicielem pozytywizmu (jak np. Asnyk), choć pod pewnymi względami był równocześnie jednym i drugim.
\end{abstract}

Dr hab. ARENT VAN NiEUKERKEN, prof. UvA - wykładowca literatury polskiej i słowiańskiej na Uniwersytecie Amsterdamskim. Zagraniczny członek Polskiej Akademii Nauk; e-mail: A.J.vanNieukerken@uva.nl; ORCID: https://orcid.org/0000-0002-4524-4637. 
Późniejszym pokoleniom krytyków i badaczy wydawało się więc, że był wczesnym modernistą, tzn. symbolistą, parnasistą albo reprezentantem jakiegokolwiek kolejnego „izmu”. Norwidologia zaczęła konstruować nowe konteksty interpretacyjne, których wspólnym elementem był status Norwida jako „prekursora". Wskutek tych kłopotów z historycznoliterackim umiejscowieniem poety ${ }^{1}$ stopniowo zapominano o jego bardzo realnym zakorzenieniu w duchowym i intelektualnym klimacie lat pięćdziesiątych i sześćdziesiątych XIX wieku (tzn. w okresie, kiedy ostatecznie wykrystalizował się jego światopogląd artystyczny). Rzecz jednak w tym, że polska norwidologia zaczęła się rozwijać w okresie, kiedy rozwój poezji (zwłaszcza francuskiej) w drugiej połowie XIX wieku był ujmowany $\mathrm{z}$ perspektywy zwycięskich tradycji modernistycznych ${ }^{2}$. Próbowano połączyć Norwida z nimi, choć z takiego punktu widzenia wiele jego poglądów i wyobrażeń wydawało się raczej, że są anachroniczne. Skupiano się więc na nowatorskiej jakości stosowanych przez niego rozwiązań formalnych. W taki sposób Norwid stał się modernistą avant la lettre (,premodernistą”) ${ }^{3}$. Czy jego „archaiczny” (albo może raczej „tradycyjny") obraz świata (choć czasami zaskakujący intuicjami wyprzedzającymi epokę o wiele lat) byłby tylko sprawą drugorzędną, obojętną dla jego ,poetyckiej” oryginalności? Jednym z celów tego tekstu jest ukazanie, że istnieje organiczna więź między ową (katolicką) anachronicznością (z punktu widzenia pozytywistów o europejskim oddziaływaniu, takich jak Ernest Renan i Émile Littré) a intelektualną oryginalnością Norwida. Owa anachroniczność do pewnego

\footnotetext{
${ }^{1}$ Czasami też usiłowano ująć specyfikę Norwidowskich wierszy właśnie z perspektywy jej właściwości niemieszczących się w ramach poetyki epoki, tzn. jej tradycji kluczowej (Janusz Sławiński). Taką „ruszoną formę” analizował Michał Głowiński w artykule „Norwida wiersze-przypowieści” (Głowiński).

${ }^{2}$ Najbardziej chyba do tego się przyczynił wydawca Pism wszystkich (Norwid, Pisma), Juliusz W. Gomulicki, który w drugim, krytycznym tomie wcześniejszego wydania poezji Norwida pt. Dzieła zebrane w komentarzu do poszczególnych wierszy analizuje Vade-mecum pod kątem dialogu z Kwiatami zła Baudelaire'a (Dzieła 2: 740-747). O „niewczesności” Norwida w kontekście ruchu parnasistowskiego wspomniała Maria Grzędzielska („Nie nawiązane ogniwo poezji” 124-150). Do relacji poetyki Norwida z symbolizmem wrócił (skupiając się na paralelach typologicznych w szerokim kontekście historycznoliterackim) Piotr Śniedziewski w książce pod znamiennym tytułem Mallarmé - Norwid. Milczenie i poetycki modernizm we Francji oraz w Polsce (Śniedziewski). Obecnie można zaś zauważyć, że coraz częściej badano światopogląd Norwida w kontekście jego epoki. Wspominam tylko o artykule Bogusława Bieli („Czy Norwid współpracował z Hyacinthe de Charencey przy pisaniu Syna Panny" - Biela) i o książkach Macieja Junkierta (Grecja i jej historia w twórczości Cypriana Norwida - Junkiert) i Dariusza Pniewskiego (Między obrazem i słowem. Studia o poglądach estetycznych i twórczości Norwida - Pniewski).

${ }^{3}$ Termin ten do norwidologii wprowadził Wiesław Rzońca w książce Premodernizm Norwida - na tle symbolizmu literackiego drugiej połowy XIX wieku (Rzońca).
} 
stopnia warunkuje późniejszą aktualność wielu jego idei (choć konteksty, które przyczyniły się do ich powstania, wydają się nam obecnie niedorzeczne).

Dość istotnym czynnikiem przy próbach ustalenia związku między twórczością Norwida a dominującymi wyobrażeniami epoki jest jego status jako przybysza z „podbitego" kraju na „peryferiach” cywilizacji europejskiej (patrząc z perspektywy Francji i Anglii; perspektywa ta jest nawet dzisiaj często uwewnętrzniona przez Polaków), a również fakt, że autor wiersza Klaskaniem mając obrzękte prawice... należał do drugiego, już trochę zagubionego pokolenia popowstaniowej emigracji polskiej. Czytając wiersze, nowele, rozprawy, szkice, a zwłaszcza listy Norwida, odnosi się wrażenie, że drugą - skądinąd pozytywną - stroną owego poczucia zagubienia była wielka wrażliwość na najnowsze prądy intelektualne we Francji Napoleona III, choć w Norwidowskiej recepcji idei pozytywistycznych zawsze uderza wspomniana już ,archaiczność” (z perspektywy pozytywistycznego agnostycyzmu) własnych poglądów poety. Ostatecznie chodziło autorowi Rzeczy o wolności stowa o obronę chrześcijaństwa, które w „centrum” ówczesnej Europy, a zwłaszcza we Francji, uległo stopniowej erozji. Aby osiągnąc ten cel, stosował on metodę rekontekstualizacji poglądów i wzorców intelektualnych typowych dla ówczesnego pozytywizmu. Próbował je umieścić w chrześcijańskiej historii świętej. Owe zabiegi rekontekstualizujące dotyczyły zwłaszcza popularnych we Francji Napoleona III językoznawstwa porównawczego, mitologii porównawczej (mitologie comparée) i tzw. teologii krytycznej, reprezentowanej przez wpływową książkę Davida Friedricha Straussa Das Leben Jesu. Kritisch bearbeitet (opublikowaną w latach 1835-1836), którą Émile Littré przełożył na francuski. Tezy Straussa uzyskały większy rozgłos dzięki Ernestowi Renanowi, który opublikował w 1863 r. artystycznie doskonałą biografię „,człowieka” Jezusa Vie de Jésus.

Podejmując motywy i obrazy związane z pozytywistyczną humanistyką, Norwid przedstawił własny obraz świata, który dzięki uwzględnieniu owych kontekstów zachował również obecnie swą aktualność. Korzenie wielu naszych współczesnych poglądów i sporów sięgają bowiem właśnie epoki pozytywizmu. Jednym z ówczesnych kluczowych pojęć była koncepcja rasy, która zarówno w mitologii porównawczej, jak i teologii krytycznej odegrała ważną rolę, kształtując perspektywę interpretacyjną uczonych w odniesieniu do genezy i rozwoju wierzeń i religii. „Rasa” była początkowo koncepcją kulturową, niekoniecznie „wykluczającą”, ale nabierała w drugiej połowie XIX wieku mniej lub bardziej świadomie charakteru narzędzia usprawiedliwiającego „zachodnią” („europejską”) dominację, do czego również (pośrednio) przyczyniły się lingwistyka i mitologia porównawcza (zwłaszcza w przypadku 
ich popularyzatorów). Trzeba wyraźnie podkreślić, że Norwid nie uległ tej tendencji, co prawdopodobnie wiązało się z jego statusem emigranta $\mathrm{z}$ „peryferii" Europy, a także z jego religijnymi przekonaniami (tzn. z jego katolickim uniwersalizmem).

Przyjrzyjmy się teraz cytatowi z jednego z listów Norwida do Joanny Kuczyńskiej (która w latach sześćdziesiątych była jego stałą korespondentką), w którym poeta zwięźle wyraził swój złożony stosunek do koncepcji rasy. Kontekstualizacja i analiza słów-kluczy („Europa”, „Azja”), imiona („Prometeusz”, „Jafet”) i pojęcie („,rasa”) pokazuje paradoksalne położenie Norwida wobec ideologicznych sporów swojej epoki:

Pani mi pisze genetyczny frazes o Scytach i Azjatach.

Jestem przeciwny systematom spółczesnym, które głoszą:

$$
\text { „Europe aux Européens!” }
$$

Selon moi - Madame! - il n'y a jamais eu des Européens, car nous tous nous sommes venus ici de l'Asie - de ce pays qui nous reste maintenant sur l'embryon de notre intelligence comme un rêve du Paradis!

Ja pochodzę od Jafetowego wnuka, co przykowany byt na szczycie Kazbeku w Kaukazie - od dziada mego Prometheusa.

Ja JEDEN przeczę temu systemowi krwi i ras. Ja jeden - ale cóż robić! - to moje mniemanie takie.

Moim zdaniem, Europa nie jest rasą, ale principium! - bo gdyby była rasą, byłaby Azją!!! (Pisma 9: 388, Do Joanny Kuczyńskiej, février, 1869)

Niestety, nie znamy treści listu, na który uwagi Norwida stanowiły odpowiedź. Ogólny kontekst jest jednak mniej więcej jasny. W dziewiętnastowiecznej świadomości Polaków relacja między Polską a Rosją była często ujmowana według wzorca opozycji między Europą a Azją, albo jeszcze inaczej - między „kulturą” a „barbarzyństwem”. W dziewiętnastowiecznych badaniach etnologicznych i językoznawczych Scytowie kojarzyli się często z Azją, a dokładniej z tzw. rasą turańską czy mongolską, na którą - według jednej ze starych tradycji - składali się potomkowie Chama (inna tradycja kojarzy Chama z pierwotnymi mieszkańcami ziemi Chanaan), choć inne badania sugerowały, że Scytowie byli Indoeuropejczykami.

W liście do Joanny Kuczyńskiej Norwid łagodzi opozycję między (scytyjską) Azją a europejską Polską ${ }^{4}$. Poeta, który określa siebie jako potomka

\footnotetext{
${ }^{4}$ Kontekstem wydają się tu poglądy Franciszka Duchińskiego, który obok wielu innych rozpraw o tzw. Turanach (mających być przodkami Moskali) napisał po francusku rozprawę pt. Peuples Aryâs et Tourans. Agriculteurs et Nomades. Nécessité des reformes dans l'exposition de l'histoire
} 
Prometeusza, stwarza kontekst łączący owe dwa kontynenty. Według jednej z tradycji mitycznych matka złodzieja ognia, którego w swoim dążeniu do rozpowszechnienia wiedzy można by potraktować jako prawzór dziewiętnastowiecznego Europejczyka dążącego do realizacji jakiejś formy uniwersalności pozwalającej zreformować świat, nazywała się właśnie Azja. Ojciec Prometeusza, Japet, był zaś często utożsamiany z biblijnym Jafetem ${ }^{5}$. W wydanym przez francuskiego duchownego Jacques'a Paula Migne (1800-1875 $)$ Uniwersalnym dykcjonariuszu mitologii starożytnej i nowożytnej (1855) podkreśla się oczywistość tego zestawienie:

[...] Les Grecs regardaient Japet comme l'auteur de leur race, et ne connaissaient rien de plus ancien comme lui. [...] Il est aisé de voir que ce Japet est le même que celui de la Bible, qui fut le père des peuples de l'Asie septentrionale et de l'Europe orientale. (Dictionnaire universel de mythologie ancienne et moderne 575)

Jeszcze bardziej przekonujący - jako że pojawia się tu Azja jako Matka Prometeusza - wydaje się następujący fragment z hasła „Japhet” w wydanym przez tegoż ojca Mignego Dykcjonarzu Biblii:

Japhet a été connu des profanes sous le nom de Japetus. [...] Sa demeure fut en Thessalie, où il se rendit célèbre par sa puissance et sa violence. Il épousa une nymphe nommée Asie, dont il eut quatre fils: Hesperus, Atlas, Épiméthée et Prométhée, qui sont tous très célèbres dans la fable ou l'histoire ancienne. Les Grecs croient que Japhet a été le père de leur race, et ils ne reconnaissent rien de plus ancien que lui [...]. (Dictionnaire de la Bible 2: 879)

des peuples Aryâs-Européens \& Tourans. Particulièrement des Slaves et des Moscovites (Duchiński). Rozprawa ta miała przekonać Francuzów, że więcej łączy ich (jako „Europejczyków”) z Polakami (a także Ukraińcami) niż z Rosjanami (Wielkorusami). Norwid wspomina o Duchińskim w liście do Leonarda Niedźwieckiego (Paryż, około 1 stycznia 1869) pisząc o opinii „utalentowanego profesora Franciszka Duchińskiego”, który „mniema, iż Niedźwiecki utrzymuje, jakoby Rosji (Turańskiej) jedność z Polską (Aryjską) zawarowaną była pierwoobowiązkowymi względami cywilizacyjnymi. Zaś Turanie i Arianie, czyli szczegółowo mówiąc np. Moskale i Polacy, w żaden sposób wedle utalentowanego profesora Duchińskiego znosić się nie mogą" (Pisma 9: 384).

${ }^{5} \mathrm{~W}$ Promethidionie Norwid utożsamia Prometeusza jeszcze z pierwszym człowiekiem, Adamem: „Prometej Adam wstał, na rękach z ziemi/ Podnosząc się [...]” (Pisma 3: 438).

${ }^{6}$ Ojciec (l'abbé) Migne (Jean-Paul Migne, 1800-1875) był francuskim księdzem i wydawcą pism patrystycznych, a także encyklopedii i słowników o teologii, mitologii, filozofii i innych naukach. Książki te (nie zawsze starannie redagowane - często chodziło o wznowienia albo kompilacje istniejących pozycji) ukazały się $\mathrm{w}$ dużych nakładach i były stosunkowo tanie. W końcu ojciec Migne stracił jednak poparcie Kościoła. Norwid wspomina o tym przedstawicielu francuskiego ultramontanizmu w Notatkach z historii: „19. Encyclopédie théologique par M. l'abbé Migne, tome 45: Dictionnaire d'iconographie. 52 tomy razem" (Pisma 7: 333). 
Podobną identyfikację tych dwóch postaci znajdujemy jeszcze w pierwszym tomie napisanego z punktu widzenia chrześcijańskiej soterologii Podręcznika historii uniwersalnej (Manuel de l'histoire universelle) Auguste'a Otta:

Il nous reste à parler de la branche japhétique des descendants de Noé. Japhet est reconnu en général pour le père des races européennes. On a signalé la ressemblance qu'offrent des noms vulgaires dans l'antiquité grecque avec ceux de Japhet et de sa postérité. Japhet (Japetos), Javan (Ion)7 . (Ott 97)

Spotykają się tu nie tylko Azja i Europa (przy czym trzeba jeszcze zwrócić uwagę na fakt, że Europa jako kontynent zawdzięczała swoją nazwę córce mitycznego króla Fenicji, Agenora), lecz także dwie różne tradycje religijne: grecka - indoeuropejska, tzn. pogaństwo - i hebrajska - semicka, tzn. monoteizm. Ciekawa pod tym względem jest jeszcze inna Norwidowska notatka z mitologii, która powołuje się na cytat ze Starego Testamentu i umieszcza Jafeta i Sema we wspólnej przestrzeni, podkreślając, że chwilowo byli (albo raczej będą, bo chodzi tu o proroctwo) współmieszkańcami. Praojciec Europejczyków jest tu przedstawiony jako gość protoplasty Semitów:

27. Sem i Jafet: od Północy i Południa.

Od środka Azji (= pozycji centralnej) ku Atlantykowi: między Hiszpanią a Chinami - Golfem Perskim a Arabią - Morzem Kaspijskim i Medyterańskim

„Inhabitet Japhet in tabernaculis Sem” (Genèse). (Pisma 7: 244) (por. Vulgata, Rdz 9, 27: „Dilatet Deus Japhet, et habitet in tabernaculis Sem, sitque Chanaan servus ejus")

Właśnie to połączenie różnorodnych - nie tylko z punktu widzenia rasy i języka, lecz także tradycji religijnych - elementów leżało u podstaw Norwidowskiej koncepcji europejskości (jako „principium”- zasady).

\footnotetext{
${ }^{7}$ Por. notatkę z mitologii 221 i 222: „Jon v. Javan (selon l'Écriture), fils de Japhet, zaludnia wyspy ze strony zachodniej Azji Mniejszej”; „Grecja - Pelazgi - niekiedy twierdzą, iż Java, Jafeta syn, daje im początek [...]" (Pisma 7: 280). O Javanie jako synu Jafeta wspomina także François Lenormant $\mathrm{w}$ pierwszym tomie popularnego wówczas dzieła o dziejach starożytnego Wschodu: „Javan ou Joun est le père des Ioniens et des Grecs. Sortis des contrées méridionales de l'Asie Mineure, les fils de Javan s'étendirent sur les côtes et dans les îles de la Mer Égée" (Lenormant 19).
} 
Norwid porusza w liście do Joanny Kuczyńskiej jeszcze inne gorąco wówczas dyskutowane zagadnienie. Wspomina o postulowanej przez dziewiętnastowiecznych językoznawców azjatyckiej praojczyźnie ludów i plemion mówiących językami indoeuropejskimi („my wszyscy przyszliśmy tu z Azji”). Wiadomo, że w latach sześćdziesiątych - a także później (dowodem jego „notatki etno-filologiczne") - Norwid interesował się żywo językoznawstwem porównawczym, łącząc - zgodnie z praktyką takich filologów jak Max Müller ${ }^{8}$ ustalenia ściśle lingwistyczne $z$ badaniami etnologicznymi i mitologicznymi. Sporo $\mathrm{z}$ jego notatek $\mathrm{z}$ mitologii i historii pochodziło właśnie $\mathrm{z}$ lat sześćdziesiątych (według Gomulickiego - z okresu 1864-1867), choć większość „,notatek etno-filologicznych" jest datowana na okres 1870-1878. List do Joanny Kuczyńskiej napisał Norwid w lutym 1869 r. Jego uwagi o szkodliwości „genetycznego frazesu" pokrywają się czasowo z pracą nad poematem Rzecz o wolności słowa, który Norwid przedstawił polskiej emigracji w Paryżu w maju 1869 r., wygłaszając go w formie „lektury publicznej”. Rok później, tuż przed wybuchem wojny francusko-niemieckiej, poemat ukazał się drukiem ${ }^{9}$. Rzecz o wolności słowa ujmuje zagadnienie genezy i rozwoju języka przede wszystkim teologicznie i historiozoficznie. Zarysowuje szeroką panoramę dziejów wcielenia i rozwoju pierwotnego słowa-logosu na ziemi. Ów proces co pewien czas przerywają katastrofy fałszujące autentyczny sens słowa. Podstawowym czynnikiem unaoczniającym dynamikę rozwojową słowa jest (podobnie jak w cytacie z listu do Joanny Kuczyńskiej) możliwość ustalenia strukturalnych podobieństw między postaciami mitologicznymi (a także biblijnymi) należącymi do różnych grup „rasowych”, tradycji religijnych i epok historycznych. Udało się Norwidowi np. skonstruować kontekst łączący greckich herosów Prometeusza i Orfeusza z żydowskim prawodawcą Mojżeszem, opisując ich - różnego rodzaju - cierpienia (chodzi m.in. o motyw „rozdartego boku") jako prefigurację Męki Chrystusowej:

Stąd Mojżesz, stąd Prometej o dobie tej saméj,

Niebieski biorąc ogień dwojakimy bramy,

Skoro jeden szemraniem ludu jest trapiony,

Drugiemu sęp wewnętrznoście maca co dzień szpony. (Pisma 3: 577)

\footnotetext{
${ }^{8}$ Dzieło Maxa Müllera pt. Mythologie comparée ukazało się w przekładzie i z przedmową Ernesta Renana w Paryżu w roku 1859.

${ }^{9} \mathrm{O}$ nieporozumieniach w związku z drukowaniem poematu zob. Norwid, Pisma 3: 771-772.
} 
Tam, na krańcach obszaru błogosławionego,

Prometej ogień poniósł - dla kogo? dla czego? -

Co dnia bok mu rozdarli. A skoro mistrz słowa,

Taki jak Orfej... serce takie... taka głowa

I taka pieśń powstanie, to w jednej wieczerzy,

Rozwarkoczonych kobiet, którym naród wierzy,

Zginie! - - (Pisma 3: 580)

Mamy w Rzeczy o wolności stowa do czynienia z bardzo specyficznie rozumianą komparatystyką mitologiczną. Mity ludzkości porządkuje Norwid zgodnie z gramatyką funkcjonalną zakorzenioną $\mathrm{w}$ dziejach słowa jako realizacji historii świętej. Dzięki takiej perspektywie mógł zestawić np. Mojżesza z Prometeuszem, mimo że Grecy byli potomkami „Ariów”, a Żydzi „semitami”. Trzeba powiedzieć, że takie podejście nie było samo w sobie niczym nowym. Podobieństwo między Mojżeszem i Prometeuszem dostrzegł, nawiązując zresztą do tradycji sięgającej późnej starożytności, pod koniec XVII wieku biskup z Avranches, Pierre Daniel Huet (1630-1721) ${ }^{10}$. W latach czterdziestych XIX wieku wspomniany już Jacques-Paul Migne, wydawca wielotomowej Encyklopedii Teologicznej, wznowił jego Demonstracje z Ewangelii (Démonstrations évangéliques) $\mathrm{w}$ francuskim przekładzie ${ }^{11}$. W czwartym rozdziale pierwszej pozycji biskup próbował udowodnić tożsamość tytana z Mojżeszem (uważanym za autora Pięciokięgu), wykorzystując wieloznaczność słowa „Azja”, będącego nazwą zarówno kontynentu, na którym żyli Hebrajczycy, jak i matki (albo według innych źródeł - żony) Prometeusza:

Prométhée est un des Cabiris, comme Esculape et Mercure. Hérodote le dit mari d'Asie; d'autres disent qu'il en était le fils; or, Moïse est originaire d'Asie, et tous les Israélites retournèrent d'Égypte en Asie. (DE 181)

Również u biskupa Hueta spotykamy utożsamienie Japeta z biblijnym Jafetem $^{12}$. Okazuje się przy okazji, że jeszcze wielu innych greckich bogów, herosów i tytanów początkowo „było Mojżeszem” (jak np. Orfeusz). U Hueta koncepcja ta była wyrazem komparatystyki mitologicznej i religijnej (już krytycznej na miarę jego epoki, choć niekwestionującej pierwotności tradycji

${ }^{10} \mathrm{O}$ biskupie Huet zob. A. Dupront, P. D. Huet et l'exégèse comparatiste au XVII siècle (Dupront).

${ }^{11}$ Demonstrations évangéliques [...] tome cinquième, contenant les demonstrations de Huet et de Clarke [dalej: DE], Petit-Montrouge [...] hors la barrière d'enfer de Paris, 1848. Książka Hueta ukazała się po raz pierwszy w roku 1679.

${ }^{12}$ Zob. DE 233-234: „Presque toute l'histoire grecque est tirée des Livres de Moïse. [...] Les Grecs ont même parlé de Japhet sous le nom de Japet”. 
hebrajskich), która się opierała na zestawieniu dostępnych biskupowi tekstów z różnych epok i tradycji (również indyjskich). Zresztą również dobrze znana Norwidowi (być może we francuskich przekładach) aleksandryjska patrystyka ${ }^{13}$ traktowała mitologię grecką jako zniekształconą odmianę pierwotnej tradycji hebrajskiej ${ }^{14}$. Chodziło $\mathrm{w}$ tej starożytnej odmianie mitologii porównawczej jednak przede wszystkim o to, by zdyskredytować autorytet greckich filozofów pogańskich poprzez ukazanie, że żyli oni znacznie później niż hebrajscy patriarchowie, którym - a zwłaszcza Mojżeszowi - zawdzięczali wszystko, co było w ich myśli wartościowe.

W drugiej połowie XIX wieku taka postawa ograniczająca się do zestawienia źródeł starożytnych i wczesnochrześcijańskich jednak już nie wystarczyła. Spekulacje mitologiczne nie mogły się obejść bez wsparcia pozytywistycznej nauki o rodowodzie mitów i rozwoju języków. Właśnie w tym kontekście trzeba zrozumieć próby Norwida udowodnienia autentyczności Mojżeszowego autorstwa Pięcioksięgu, przy czym próbuje on wykorzystać współczesną mu wiedzę filologiczną, mitologiczną i językoznawczą, by wesprzeć stanowisko Ojców Kościoła, którzy podawali w wątpliwość rzekomo wcześniejszy rodowód świętych ksiąg Egipcjan, Babilończyków i Fenicjan. Poeta rozszerza przy tym owe badania o obszary, które były jeszcze nieznane pierwszym doktorom Kościoła. Interesowały go więc również wierzenia Indów i Chińczyków, systematycznie badane przez współczesną mu orientalistykę. Norwid całymi garściami czerpał z lingwistycznych i mitologicznych badań pozytywistów, choć istotnie zmienił wymowę odkrytych przez nich faktów, umieszczając je w kontekście historii świętej. Zasadniczo akceptując osiągnięcia mitologii i lingwistyki porównawczej, uznał jednak, że ich wyniki nie relatywizują prawdziwości dziejów wcielenia Słowa w Chrystusa. Oczyszczone przez pozytywistycznych historyków i filologów z zabobonu „fakty” wskazują więc na historię świętą, lecz ona sama pozostaje - z punktu widzenia Norwida - poza wszelkim podejrzeniem.

${ }^{13}$ Por. wstęp do Dictionnaire universelle de mythologie ancienne et moderne: „Nous aurions essayé de montrer qu'à travers de tant de fables extravagantes [...] il y a de vestiges ineffaçables de traditions identiques et puisées à une source commune, telle que la Bible nous la présente, dans les origines des temps. Quel bonheur nous éprouverions à nous appuyer sur le témoignage si recommendable des Pères de l'Église, dont quelques-uns, après avoir d'abord été païens, avaient certainement étudié et connu les mystères, les pratiques et les croyances du paganisme" (VIII-IX).

${ }^{14}$ Por. następujące twierdzenie z Demonstrations évangéliques: „Presque toute la théologie païenne a sa source dans la personne de Moïse, dans les diverses circonstances de sa vie ou de ses écrits" (DE 1319). Nie tylko wierzenia starożytnych Greków, ale również Indowie, Persowie, Chińczycy i Japończcy dużo zawdzięczają Mojżeszowi: „L'ancienne religion des Perses a sa source dans les livres de Moïse. [...] l'ancienne religion des Indiens est puisée dans les livres de Moïse. [...] Les Chinois et les Japonais ont aussi profité des livres de Moïse” (DE 1319). 
Teologię krytyczną w wydaniu Davida Friedricha Straussa i Ernesta Renana sprowadzającą treść Pisma Świętego do relacji historycznych sensu stricto, „kontaminowanych” przez elementy wyobraźni mitycznej, Norwid oczywiście odrzucał. Łatwo się przekonać, że Norwidowskie podejście do mitologii pod wieloma względami jest zbliżone do perspektywy biskupa Hueta, który zgodnie z tradycją patrystyczną, a także z późniejszymi ortodoksyjnymi tradycjami egzegetycznymi - uważał, że najważniejsze postacie ze Starego Testamentu stanowią prefiguracje Chrystusa ${ }^{15}$. Ponieważ uczony biskup z Avranches wcześniej w swoim dziele udowodnił, iż herosi z mitologii starożytnej są wcieleniami biblijnych mężów, powstał paradygmat interpretacyjny, który stwarzał warunki dla pośredniego zestawienia (jak w wyżej przytoczonym tekście z Rzeczy o wolności stowa) herosów z mitologii starożytnej z Chrystusem. Wydaje się jednak, że właśnie dzięki tej - zdaniem Renana - staroświeckiej postawie ${ }^{16}$ Norwid okazał się odporny na pokusy ideologii rasistowskiej, która stopniowo zaczęła się wyłaniać z jednostronnie wyjaśnianych odkryć nowoczesnych filologów. Nie oznaczało to jednak, że autor „notatek etno-filologicznych" nie zapoznał się z ich badaniami.

We Francji okres rozkwitu językoznawstwa porównawczego (jako zjawiska wykraczającego poza waską sferę akademicką) przypada na lata pięćdziesiąte i sześćdziesiąte XIX wieku. Łączono je często - jak już widzieliśmy - ze studiami nad genezą i wzajemnym oddziaływaniem mitów. Uważano bowiem, że mity są wyrazem świadomości ludzi należących do danej grupy lingwistycznej u początków jej istnienia. Czasami - ale nie zawsze - stawiano znak równości między grupą językową (np. językami „aryjskimi”, tzn. indoeuropejskimi) a koncepcją rasy $\mathrm{w}$ sensie determinacji fizycznej ludzkich grup (Norwid zresztą na ogół odrzucał takie zestawienie ${ }^{17}$ ). Dzieje ras łączono

\footnotetext{
${ }^{15}$ Por. DE, rozdz. CLXX (,Sur les diverses figures de Jésus-Christ qu'on trouve dans l'ancien Testament”), w szczególności s. 917-918 („Moïse est la figure de Jésus-Christ”).

${ }^{16}$ Por. esej, który Renan napisał o francuskim przekładzie dzieła Friedricha Creuzera poświęconego religiom starożytności (Religion de l'antiquité): „heureux quand, résistant aux préoccupations qui séduisirent Pochart, Huet, Bossuet et toute l'école théologique, ils ne cherchaient pas dans la mythologie grecque une forme altérée des traditions de la Bible" (Des religions de L'antiquité et leurs derniers historiens, RdDM 1853: 825).

${ }^{17}$ Por. następującą „,notatkę z mitologii”: „,86. [...] Błędne mniemanie pochodzeń ludów po językach: języki macierzyste i pochodnie. Błąd - one są wszystkie siostry rodzone. Trzeba w głąb zejść. [...]" (Norwid, Pisma 7: 254).
} 
natomiast $\mathrm{z}$ historią ziemi i życia $\mathrm{w}$ szerszym sensie, badanymi przez geologię i paleontologię. $Z$ punktu widzenia francuskiego pozytywizmu nauki filologiczne i historyczne ze swej istoty wiązały się z nauką przyrody w najszerszym tego słowa znaczeniu. Stanowiły bowiem najwyższy dotąd etap w hierarchii naukowych badań nad rozwojem wszechświata. Wymowne pod tym względem jest stanowisko Ernesta Renana, który opublikował w roku 1863 w „stale przez Norwida czytywanej” (Norwid, Pisma 7: 707) Revue des Deux Mondes (RdDM) artykuł pt. Les sciences de la nature et les sciences historiques. W tym tekście, który zwięźle przedstawia pozytywistyczny program naukowy, Renan wylicza siedem „epok” składających się na całokształt rzeczywistości. Po epokach „atomowej”, „molekularnej”, „solarnej”, „planetarnej”, „rozwoju indywidualnego każdej planety”, kiedy „ziemia przechodzi kolejne ewolucje objawione przez geologię" i kiedy „pojawia się życie”, i - w konsekwencji „botanika, zoologia i fizjologia znajdują swój przedmiot”, nadchodzi szósta epoka „nieświadomej ludzkości, którą nam objawia filologia i mitologia porównawcza”, trwająca aż do czasów historycznych. Zaczęły one „świtać w starożytnym Egipcie" (RdDM 1864: 769). Wniosek Renana brzmi następująco:

W sumie, co nazywa się historią, jest historią ostatniej godziny, jakby - aby zrozumieć dzieje Francji - zostaliśmy ograniczeni do wiedzy o tym, co zdarzyło się do dziesięciu lat wstecz. (RdDM 1864: 769)

Mamy jednak (pośredni) dostęp do tych dawniejszych epok wszechświata dzięki dwóm czynnikom, albo może raczej dzięki temu, że istnieje istotna współzależność między nimi. Czas łączy się bowiem z ruchem postępującym (wzwyż) i właśnie to tłumaczy rzeczywistość coraz bardziej złożonych bytów: „Deux élements, le temps et la tendance au progrès, expliquent l'univers. [...] Sans ce germe fécond de progrès, le temps reste éternellement stérile" (RdDM 1864: 769). Następnie Renan, wykraczając poza perspektywę nauk eksperymentalnych i powołując się explicite na Hegla, utożsamia Boga $\mathrm{z}$ - na razie jeszcze nieurzeczywistnioną - całością wszechświata jako organem złożonej samoświadomości. W tym kontekście zestawia Chrystusa z Sokratesem i Buddhą, jako że „Bóg jest nie tylko immanentny w całości wszechświata, lecz także w każdym z bytów na nią się składających z osobna" (RdDM 1864: 773). Jego samoświadomość (poznaje siebie bowiem poprzez swoje byty) stopniowo wzrasta i osiąga swój - tymczasowy - szczyt w człowieku-geniuszu.

Panteistyczna metafizyka Renana - bo jak inaczej nazwać intuicję wszechświata, którego zwieńczenie stanowi stan, w którym „duch będzie wszechmocny, a idea całą rzeczywistością" (RdDM, 1864: 774) - była Norwidowi oczywiście 
obca, ale teoria hierarchicznie ustrukturowanego rozwoju bycia przypomina jego koncepcję dziejów słowa. Narzędziem zarysowania dziejów słowa jest przy tym (wspólnie z już omawianą mitologią porównawczą) językoznawstwo porównawcze. Właśnie spory ówczesnych językoznawców pozwalają nam lepiej zrozumieć negatywną reakcję Norwida (w liście do Joanny Kuczyńskiej) na bardziej skrajne (choć podpierające się postawą „scjentystyczną") odmiany dziewiętnastowiecznego dyskursu rasowego (ideologiczne w tym sensie, że służyły „zachodniej” dominacji geopolitycznej). Podważały one bowiem ideę „jedności rodzaju ludzkiego”, bez której uniwersalność chrześcijańskiej koncepcji zbawienia (poprzez Mękę Chrystusową) stałaby się bezprzedmiotowa. Ważnym elementem tego dyskursu była wspomniana już koncepcja praojczyzny wszystkich narodów, które mówiły językami indoeuropejskimi (właśnie w tym kontekście wspomina się na ogół o „Ariach”). Swoją wiedzę o azjatyckiej praojczyźnie Ariów Norwid czerpał z różnych źródeł. Na jedno z nich trzeba tu zwrócić uwagę ze względu na jego znaczenie dla późniejszego rozwoju dyskursu rasistowskiego.

Jednym z popularyzatorów tego dyskursu z perspektywy językoznawstwa był Émile Louis Burnouf (1821-1907), bratanek indologa Eugène'a Burnoufa ${ }^{18}$, dyrektor liceum francuskiego w Atenach i autor książek takich, jak Histoire de la littérature grecque (1869) i Le science des religions (1872). W recenzji, która również ukazała się w Revue des Deux Mondes, zreferował poglądy niemieckiego językoznawcy (Friedricha) Maxa Müllera (1823-1900) ${ }^{19}$, przy czym skłaniał się - w odróżnieniu od niego - do poglądu, że podstawowe grupy językowe powstały w różnych miejscach, czyli w izolacji od siebie. Duch języka określa do pewnego stopnia koncepcję człowieczeństwa uznawaną przez daną „rasę”. Max Müller, który zajmował się również mitologią i „teologią" porównawczą, explicite odrzucił przełożenie swych tez lingwistycznych na kategorie „fizjologiczne”. Właśnie tak postąpił Émile Burnouf, który uważał, że można również odwrócić tę relację. Rasa, włącznie z cechami fizycznymi należących do niej ludzi, stanowi o charakterze budowanej przez nich cywilizacji, o jej wyobrażeniach filozoficznych i religijnych, które znajdują również wyraz w strukturze języka. Pogląd ten dzieli Burnouf z również (i w tym samym czasie) publikującym w Revue des Deux Mondes paleontologiem i botanistą Gastonem de Saportą (1823-1895), który (w artykule pt. La paleontologie

\footnotetext{
${ }^{18}$ Eugène Burnouf był autorem obszernego „Wprowadzenia do dziejów buddyzmu indyjskiego” (Introduction).

${ }^{19}$ Bliżej przyjrzę się tej recenzji, która była prawdopodobnie znana Norwidowi (zwóciły na to uwagę autorki Kalendarza życia Cypriana Norwida), w ostatniej częściej artykułu.
} 
appliqué à l'étude des races humaines) uważał, że np. człowieczeństwo Chińczyka nie miało nic wspólnego z europejskimi („naszymi”) wyobrażeniami o człowieku ${ }^{20}$, zarówno z punktu widzenia języka i ducha cywilizacji, jak i cech fizycznych:

En plaçant vers l'Asie intérieure le berceau des grandes races historiques, on obtient un premier groupement dont les termes extrêmes se trouvent déjà séparés par un intervalle énorme, puisque, selon l'expression de M. Renan, les Chinois sembleraient représenter une autre humanité, n'ayant rien de commun avec la nôtre, qu'on se place au point de vue de langage, des traits physiques ou de la civilisation. Si l'on admettait, comme le veut M. Max Müller, que chaque famille de langues correspond à l'une des periods par lesquelles le langage humain a dû passer, il en résulterait que les races qui les parlaient seraient des rameaux succesivement détachés du même tronc; les divergences seraient proportionelles au temps écoulé depuis la séparation de chaque rameau $[\ldots]$. [...] mais cette convergence rétrospective, en apparence si favorable à la théorie des monogénistes, serait encore loin de prouver l'unité de la race humaine. (RdDM, 1868: 989)

Saporta omawia tu elementy lingwistycznych teorii Maxa Müllera, które miały ex post (,cette convergence rétrospective”) uprawdopodobnić tezę, że wspólna geneza języków należących do różnych grup nie jest niemożliwa (co byłoby również argumentem na rzecz wspólnego pochodzenia rodzaju ludzkiego - „la théorie de monogénistes” sprzyjającej z teologicznego punktu widzenia uniwersalności zbawienia przez Chrystusa). Burnouf skupia się zaś bezpośrednio na różnicach między grupami języków (interesuje się szczególnie stosunkiem języków „aryjskich” do języków „semickich”), przy czym kategoria

\footnotetext{
${ }^{20}$ Ów paleontobiolog przywołał w tym kontekście zarówno Renana - jako autora znanej Norwidowi Histoire générale et système comparée des langues sémitiques - jak i Maxa Müllera (La science du langage). Wspomina ponadto o wielkiej rodzinie turańskiej, której kolebką miały być góry altajskie (RdDM 1868: 984). Rasa ta - w odróżnieniu od Norwida Saporta cały czas utożsamia język z pochodzeniem etnicznym - miała się początkowo nawet fizycznie odróżnić nie tylko od ludów aryjskich, lecz także od semickich. Trafiła ona podobno wcześniej niż Ariowie do Europy (RdDM 1868: 988). Plemiona turańskie zamieszkały stepy na pograniczu Rosji, między Donem a Morzem Kaspijskim, lecz zdaniem Saporty - który powołuje się tu na Herodota - nie należy ich mylić z prawdziwymi Scytami, „których pochodzenie aryjskie nie ulega wątpliwości”. Od Scytów odróżniały ich m.in. ich spłaszczone nosy: „On distingue même dans le récit d'Hérodote des nations associées aux Scythes, mais d'une origine différente [...]. On reconnait là des tribus errantes d'origine touranienne" (RdDM 1868: 983). Niewykluczone, że protest Norwida przeciw „genetycznemu frazesowi” w liście do Joanny Kuczyńskiej był właśnie reakcją na artykuł Saporty, tym bardziej że autor wspomina w nim także o - położonej również w Azji środkowej i sąsiadującej z kolebką ludów turańskich - praojczyźnie Ariów (Norwid mówi o Turanach („Scytach azjatyckich u historyków greckich") w notatce mitologicznej 335 (Pisma 7: 306).
} 
rasy okazuje się bardziej podstawowa, „pierwotna” niż kategoria języka. Owe różnice rasowe wyrażają się ponadto $\mathrm{w}$ odmiennym duchu semickich religii monoteistycznych - judaizmu i islamu - w porównaniu z religijnymi wyobrażeniami skłonnych do panteizmu Ariów (zobaczymy jeszcze, że pod tym względem Burnouf powtarzał E. Renana, choć autor Życia Jezusa zazwyczaj unikał wnioskowania o wyższości czy niższości ras albo religii). Z pozycji intelektualnej Burnouf zastanawiał się nad charakterem chrześcijaństwa, w którym dominujący pierwiastek judaistyczny, tzn. semicki, kłóci się - jego zdaniem - z pewnymi pierwiastkami aryjskimi zaczerpniętymi z grecko-rzymskiego ducha cywilizacji starożytnej. Jego koncepcja rasowej determinacji języków i stwarzanych przez nie systemów intelektualnych (dotyczy to więc również religii) znajduje się na przeciwstawnym biegunie wobec przekonania biskupów Hueta i Bossueta (przejętego przez dziewiętnastowiecznych francuskich polemistów katolickich, a także przez Norwida ${ }^{21}$ ), że wszystkie wierzenia ludzkości wypływają z jakiegoś pierwotnego objawienia, które uległo później odkształceniu (jedność religijną Burnouf wyobraża sobie, zgodnie z pozytywistyczną reinterpretacją Heglowskiej filozofii Ducha, dopiero u kresu rozwoju ludzkości). Burnouf dyskwalifikuje ów pogląd poprzez wskazanie na jego nienaukowość. Istotnym argumentem okazuje się tu nieznajomość „porównawczego badania języków”, które „oddziela początki idiomów semickich od idiomów aryjskich”, przy czym językoznawstwo porównawcze wiąże się ściśle ze studiami nad rasami:

Beaucoup de chrétiens supposent que toutes les religions de la terre procèdent d'une révélation primordiale, dont elles ne sont guère que des corruptions diverses. $\mathrm{Ce}$ n'est pas là sans doute un article de foi, mais c'est une idée qui s'est beaucoup répandue depuis l'époque où Bossuet composait son Histoire universelle avec des données tout à fait insuffisantes. Depuis lors la science a marché ; il n'est pas un savant aujourd'hui qui ne considère cette opinion comme fausse : elle est contredite à la fois par la connaissance des textes, qui ne montrent aucun point de contact entre les livres hébreux et le Véda, par l'étude comparée des langues, qui sépare dans leurs origine les idiomes sémitiques des idiomes âryens, par celle des races humaines, que l'on voit se succéder les unes aux autres suivant leur ordre de perfection [...]. Si donc les chrétiens admettent la réalité d'une révélation religieuse primordiale, ile faut qu'ils se mettent d'accord avec la science, et qu'au lieu de voir dans les diverses religions autant de dégradations de la vérité divine, ils les regardent comme des tentatives humaines par lesquelles les nations s'acheminent peu à peu vers le chri-

${ }^{21} \mathrm{~W}$ jednej z notatek z historii Norwid zwraca uwagę, że „Chrystianizm“ uzasadniał historię „przez jedyność Boga i jedyność rodu ludzkiego”. Następnie kojarzy Bossueta z teokratycznymi poglądami Mojżesza: „Bossuet (z Mojżeszem) ludy pod wodzą Bożą uznaje” (Norwid, Pisma 7: 366). 
stianisme. (Burnouf, La science des religions. Sa méthode et ses limites II, Les grandes religions et leur origines, RdDM 1864 : 986-987)

Podstawa argumentów Burnoufa (istotna relacja między grupami językowymi a „rasami”, włącznie z „hierarchią” ras) była dla Norwida zupełnie nie do przyjęcia, ale uwaga Burnoufa (który tu tylko powtórzył obiegową tezę pozytywistyczną), że idea pierwotnego objawienia w postaci sformułowanej przez biskupa Hueta (a także przez Bossueta) jest „nienaukowym” anachronizmem, zrobiła na poecie pewne wrażenie. Francuski publicysta postuluje więc, że ,jeżeli chrześcijanie przyjmują realność pierwotnego objawienia religijnego, powinni uzgodnić ją z nauką", a interpretację rozmaitych wierzeń jako kolejnych spaczeń (dégradations) boskiej prawdy zastąpić koncepcją odwrotną, dopuszczającą postęp poprzez rozwój i zmianę. Wierzenia i religie byłyby wtedy ludzkimi próbami, poprzez które „narody podróżowały stopniowo ku chrześcijaństwu”. Rzecz o wolności słowa usiłuje właśnie pogodzić chrześcijańską koncepcję dziejów ze współczesnymi Norwidowi badaniami nad mitami i religiami, choć z punktu widzenia pozytywistycznego poeta uwikłał się w nierozwiązywalne sprzeczności, będąc co do istoty swych rozmyślań bliższy biskupom Huetowi i Bossuetowi niż Renanowi i Burnoufowi.

Ślady polemiki polskiego poety z pozytywistyczną dyskredytacją idei pierwotnego objawienia można znaleźć właśnie w jego notatkach z mitologii, historii i językoznawstwa. Co ciekawe, jedna z nich - chodzi tu o „notatkę etno-filologiczną" - przywołuje explicite świadectwo i autorytet Maxa Müllera (według Gomulickiego owe notatki etnofilologiczne powstały jednak później niż notatki z mitologii i historii oraz list Norwida do Joanny Kuczyńskiej (luty 1869), a mianowicie między latami 1870-1878 (Norwid, Pisma 7: 706) - notatka pokazuje jednak dobrze sposób, w jaki poeta wykorzystał ówczesną wiedzę naukową):

109. Czy jedno źródło mnogość zaprzecza?

Max Müller wnioskuje, że tak być może.

Indoeuropejskie - chiński - amerykańskie - semickie - fińskie i hotentockie żadnego śladu spólnego pochodzenia. Max Müller: niech dowodzą pierwej niemożliwości pogodzenia. (7: 393)

Punktem spornym jest tu więc zagadnienie, które poruszył Burnouf w kontekście starej koncepcji teologicznej przyjmującej jakieś pra-objawienie: czy każda $\mathrm{z}$ istniejących grup językowych stanowi samoistny typ nieredukowalny do innych grup, czy też - przeciwnie - należy owe grupy traktować jako 
ogniwa w szerszym procesie rozwoju języka (Norwid powiedziałby: stopniowe „wywoływanie” z człowieka „słowa”)? Gdyby się zaś okazało, że np. kolebka języków indoeuropejskich nie była prakolebką jakiegoś plemienia (rasy) - tzn. Ariów - tożsamą z pewną grupą językową, lecz kolejnym etapem w historii języka, wywodzącym się z nieznanego - i w ramach metodologii pozytywistycznej - niepoznawalnego źródła wspólnego wszystkim grupom językowym, uległby również zakwestionowaniu absolutny charakter różnic między rasami. Norwid, powołując się tu na badania Maxa Müllera, który stronił od wniosków mogących uzasadnić dziewiętnastowieczny dyskurs rasowy, zdawał sobie doskonale sprawę z wagi tego zagadnienia (choć nie zawsze był tak konsekwentny). Stanowisko niemieckiego językoznawcy dałoby się bowiem pogodzić (w każdym razie nie wyklucza go) z teologiczną koncepcją przyjmującą jedność historii ludzkiej (,przez jedyność Boga i jedyność rodu ludzkiego" - Norwid, Pisma 7: 366 - notatka z historii 158, w której św. Augustyn sąsiaduje z Bossuetem).

Trzeba jednak powiedzieć, że stawiając - choćby implicite - znak równości między zagadnieniem wspólnego źródła języków, nie tylko indoeuropejskich, opierających się na fleksji, i semickich, lecz także „turańskich”, realizujących zasadę aglutynacji, a pochodzeniem wszystkich ludów od Adama, Norwid nie tylko przeciwstawiał się Burnoufowi, któremu nie podobała się powściągliwość niemieckiego uczonego w łączeniu wyników językoznawstwa porównawczego z badaniami nad rasami. Oddalił się również od metodologicznej podstawy poglądów Maxa Müllera, zbliżając się natomiast do stanowiska współczesnej mu apologetyki katolickiej, która traktowała nową, sensu stricto naukową probę uzasadnienia hipotezy o wspólnym źródle różnych grup językowych jako swoisty dowód prawdziwości relacji biblijnych o raju i upadku pierwszego człowieka. Norwidowska „notatka etno-filologiczna” odwołuje się prawdopodobnie do następującego twierdzenia niemieckiego językoznawcy z - przełożonego na francuski - „kursu o nauce języka” (Leçons sur le science du langage" - LSdL):

Vous remarquerez que dans ce que je viens de dire j'ai cherché à établir la possibilité, et non la nécessité, d'une origine commune du langage. Je regarde ce problème, lequel, ainsi que nous l'avons vu, n'a rien à faire avec celui de l'unité primitive de l'humanité, comme une question qui doit rester indécise le plus longtemps possible. (LSdL 417-418) [...]

Or, j'avoue que, quand j'ai vu soutenir mainte et mainte fois qu'il n'est plus possible de parler de l'unité primitive du langage, depuis que la philologie comparée a prouvé l'existence de diverses familles de langue, j'ai senti que l'argument n'était 
pas concluant, qu'il allait, en tout cas, beaucoup plus loin. Le problème, envisagé sous son véritable aspect, se réduit à ceci :- «Si vous voulez affirmer que le langage a eu des commencements différents, il faut prouver qu'il est impossible que toutes les langues aient eu une origine commune.» (LSdL 419)

Celem rozważań Maxa Müllera o możliwości wspólnego źródła języka było podważenie przekonania, iż na podstawie badań porównawczych można udowodnić, że języki nie pochodzą z takiego wspólnego źródła (przyjęcie tej tezy byłoby potencjalnym argumentem - jak u Burnoufa - na rzecz rasistowskich tez). Pozostając wiernym pozytywistycznemu przekonaniu, że nauka nie może się wypowiadać o pierwszych początkach i finalnych celach, niemiecki językoznawca odwraca ostrze argumentu zwolenników tezy o wielości źródeł języka. Jego zdaniem współczesny stan badań nie pozwala udowodnić hipotezy, że „wszystkie języki nie mają wspólnego pochodzenia”. Norwid skwapliwie wykorzystał tę negatywną tezę po to, by osiągnąc cel pozytywny. Próbował w Rzeczy o wolności słowa pokazać, że to właśnie teologiczny punkt widzenia jest prawomocny - można bowiem zarysować historię języka (języków) jako realizację dziejów Słowa-Logosu, tzn. pogodzić fakt istnienia wielości grup językowych z ,jedynością Boga i rodu ludzkiego”, choć współczesny mu stan badań językoznawczych wydawał się przeczyć objawionemu świadectwu historii świętej (por. „Indoeuropejskie - chiński - amerykańskie - semickie - fińskie i hotentockie żadnego śladu wspólnego pochodzenia. Max Müller: niech dowodzą pierwej niemożliwości pogodzenia" Norwid, Pisma 7: 393). Podejście Norwida wykorzystuje wyniki konsekwentnie realizowanej metodologii pozytywistycznej (nie sposób się wypowiadać o pierwszych początkach i ostatecznych celach) w sposób właśnie „nienaukowy”, choć w odróżnieniu od Burnoufa, który uważał siebie za „naukowca”, poeta nie pretendował w swym „orfejskim” poemacie do naukowości. Wierzył jednak, że chrześcijańskie objawienie i poetycka wyobraźnia wyżej stoją niż ścisła, nie natchnięta nauka pozytywistyczna.

O niebezpieczeństwie uogólnień uzależniających wartość poszczególnego człowieka od wyznaczników rasowych Norwid przekonał się, czytając kolejne teksty o religii w kontekście językoznawstwa i mitologii komparatystycznej, które między latami 1863 i 1870 w Revue des Deux Mondes opublikował wspomniany w poprzednim rozdziale Émile Burnouf. W tych tekstach (zebrał 
je kilka lat później w swojej książce o nauce religii - La science des religions) opisuje krainę, w której powstał pierwotny język indoeuropejski, podkreślając rasową czystość zamieszkujących ją Ariów. Norwid interesował się żywo ową mityczną kolebką środkowoazjatycką języków „aryjskich”. Świadczy o tym nie tylko list do Joanny Kuczyńskiej, z którego przytoczono fragment na początku tego artykułu, lecz także część notatek z mitologii, które pochodzą z lat, kiedy Norwid pracował nad Rzecza o wolności stowa. Ciekawa pod tym względem jest zwłaszcza następująca notatka:

75. Z wysokości azjackich płyną ludy i rozdzielają się w dwa pasma: jeden ku środkowi kontynentu, na Wschód, i tam przylega... drugi ku Europei dalej - dalejw XV wieku pod przywództwem Kolumba dalej jeszcze, i Nowy Świat odkrywa, i obiega glob, i łamie mury chińskie! (Norwid, Pisma 7: 251)

Czytającemu owe notatki mitologiczne trudno się oprzeć wrażeniu, że Norwid znał teksty religioznawcze Burnoufa i że jego znajomość językoznawczych koncepcji Maxa Müllera została w tym okresie przynajmniej częściowo zapośredniczona przez francuskiego filologa (notatka etnofilologiczna, w której cytowano niemieckiego uczonego, powstała jednak według Gomulickiego po roku 1870). W 1867 r. Burnouf opublikował w Revue des Deux Mondes obszerny artykuł (recenzję) poświęcony dziełu Lectures on the Science of Language delivered at the Royal Institution of Great Britain by Max Müller ${ }^{22}$ ). Innym - już dawno zauważonym przez norwidologię - źródłem informacji o Müllerze i „aryjskich” ruchach migracyjnych były teksty Renana (myślę tu zwłaszcza o wprowadzeniu do przełożonego przez niego Eseju o mitologii porównawczej [Essai de mythologie comparée, trad. De l'anglais de M. Max Müller..., Paryż 1859]). Jeżeli chodzi zaś o wyżej zacytowaną notatkę Norwida o „wysokościach azjatyckich” jak kolebce rozmaitych ludów, to może być ona związana z fragmentem innego artykułu Burnoufa, który ukazał się w Revue des Deux Mondes, zatytułowanego Cywilizacja chrześcijańska na Wschodzie - Indie Brytyjskie pod rządami królowej Wiktorii (1865):

${ }^{22}$ Zofia Trojanowicz i Elżbieta Lijewska, autorki Kalendarza życia i twórczości Cypriana Norwida, zwracają uwagę (t. 2: 331), że Norwid czytał - w roku 1867 - recenzję dzieła Maxa Müllera (La science du langage. Letters on the Science of Language delivered at the Royal Institution of Great Britain, by Max Müller; 2 vol. in 8- ${ }^{\circ}$. London 1861-1844 - RdDM, vol. 67, 1867: 274-306). Widzieliśmy wcześniej, że notatka etnofilologiczna 109 jest związana z tym dziełem, które właśnie w tym roku ukazało się we francuskim przekładzie. 
Ce fait, c'est l'identité d'origine entre les hautes classes indiennes et les peuples européens.[...] Il n'y a plus là d'hypothèse: la fraternité primordiale des IndoEuropéeens est une vérité scientifique. [...] On sait en outre que ce n'est pas sur le Gange ni même sur l'Indus qu'il faut chercher leur commun berceau, mais au nordouest de la presque'île indienne, au-delà d'Attock et de Peshawer, dans les vallées qui descendent de l'Indou-Kô et qui se dirigent vers la Mer d'Aral et la Kaspienne. A des époques qu'il est à peu près impossible de fixer, les migrations de la race aryênne partirent de là et se dirigèrent les unes vers le ouest, les autres vers le sudest. Les premières peuplèrent une grand partie de l'Asie occidentale, l'Europe presque entière, atteignirent les îles britanniques et l'Irlande, dont le nom signifie terre des Ires ou Aryas. Enfin, avec les Normands et plus tard à la suite de Christophe Colomb, ells franchirent l'Atlantique et conquirent le Nouveau Monde, dont elles se disputent aujourd'hui la possession [...] Ainsi à l'est et à l'ouest nous rencontrons des hommes qui furent autrefois nos frères [...]. (La civilisation chrétienne en Orient - l'Inde anglaise sous la reine Victoria, RdDM 1865: 615-616)

Teza sytuująca praojczyznę ludów indoeuropejskich w Azji Środkowej jest oczywiście - jak widzieliśmy - wspólna dla całej dziewiętnastowiecznej filologii porównawczej, choć nie wszyscy ówcześni uczeni ją akceptowali.

Bardziej istotny jest tu jednak przewrotny sposób, w jaki Norwid wykorzystuje tę myśl: nie tylko w liście do Joanny Kuczyńskiej, lecz także - implicite - w zacytowanej notatce o ruchach „migracyjnych”. Właśnie ukryta polemika z udającymi naukowość tezami Burnoufa i jemu podobnych pozwala uwydatnić oryginalność Norwidowskiej strategii, która wykazała niespójność dziewiętnastowiecznego dyskursu rasistowskiego. Stereotypy rasistowskie zostają przez Norwida bowiem unieważnione za pomocą „naukowych” ustaleń, które w pewnych warunkach ( $\mathrm{w}$ istocie chodziło tu o nadużycie językoznawstwa porównawczego) okazały się szczególnie podatne na ,genetyczny frazes" (zob. list do Joanny Kuczyńskiej). Norwid i Burnouf zgadzają się wprawdzie, że część owego aryjskiego „praludu” - może jednak później niż niektóre ludy turańskie - trafiła ze środkowoazjatyckiej kolebki do Europy. Konsekwencje tego stanu rzeczy są jednak paradoksalne. Zarówno na Wschodzie, jak i na Zachodzie „spotykamy ludzi, którzy byli kiedyś naszymi braćmi” (twierdzi Burnouf). Brytyjczycy, podbijając Indie, spotykają potomków swoich własnych przodków. Norwid podkreśla natomiast rolę Europejczyków w odkryciu Ameryki (Kolumb był z jego punktu widzenia „postfiguracją” Chrystusa). Przynosząc tym kontynentom nowe światło chrześcijaństwa, Europejczycy zapoznają ich jednak z wiarą, która (według ówczesnych badań w zakresie mitologii porównawczej) ma niewiele wspólnego z wierzeniami dawnych Ariów, którzy - zdaniem Renana i Burnoufa - mieli raczej skłonność do 
panteizmu. Narodziny chrześcijaństwa byłyby bowiem nie do pomyślenia bez duchowego wkładu należących do innej grupy językowej Semitów, którzy zdaniem Renana - ale już nie Burnoufa - posiadali geniusza wybitnie religijnego. Właśnie oni byli twórcami monoteizmu, będącego ich „pierwotną intuicją”.

Przekonanie o tym semickim geniuszu religijnym autor słynnej książki o życiu Jezusa sformułował w kontekście przeciwstawiającym „rasie niesłusznie nazywanej semicką” „rasę indoeuropejską obejmującą szlachetne ludy Indii, Persii, Kaukazu i całej Europy". Według Renana człowiek indoeuropejski był w odróżnieniu od ludów semickich - za bardzo zanurzony w zjawiskach przyrody. Jedność i jedyność Boga nie może zaś być wnioskiem logicznym (jak u Greków) ani wynalazkiem opierającym się na doświadczeniu zmysłowym (ogólna postawa indoeuropejska). Różnica między Renanem a Burnoufem polega więc na tym, że dyskurs autora Życia Jezusa odwołuje się wprawdzie do różnic między rasami, ale zachowuje równowagę w swym wartościowaniu. Zarówno ludy semickie (zwłaszcza Żydzi), jak i ludy aryjskie mają swego własnego geniusza, rzeczywiście ściśle związanego z naturą ich języków. Okazuje się jednak, że wytwory owego geniusza nie są wyłączną własnością danej rasy, lecz również mogą być doceniane - i czasami nawet dalej rozwijane - przez ludy należące do innych ras. Tak właśnie ma się sprawa z twórczością religijną Żydów. Na przykład arcydzieło ich poezji religijnej, Psalmy Dawida, pod każdym względem przewyższa - zdaniem Renana - literaturę religijną Indów. Zakrawa na paradoks, że to właśnie „my”, potomkowie ludów indoeuropejskich, przodując w sprawach wojskowych, politycznych i intelektualnych (E. Renan, Du peuple d'Israël et de son histoire, RdDM 1855: 752 artykuł ten jest omówieniem dzieła niemieckiego teologa i historyka Heinricha Ewalda pt. Geschichte des Volkes Israel bis Christus, Göttingen, 1854), zdajemy sobie sprawę z tej wyższości „semickiej” twórczości religijnej. Poglądy niewierzącego, ale czującego sympatię dla pierwotnego chrześcijaństwa Renana pokrywają się tu dokładnie z opinią Norwida. Psalmy były zjawiskiem o wielkim znaczeniu dla historii umysłowości ludzkiej, z którym „pierwsze pieśni rasy, do której my należymy" (chodzi o Wedy), nie wytrzymują porównania, choć są dziełem „rasy tak odmiennej od naszej”:

C'est certainement une admirable poésie que celle des Védas, et pourtant ce recueil des premiers chants de la race à laquelle nous appartenons ne remplacera jamais, dans l'expression de nos sentiments religieux, les Psaumes, oeuvre d'une race si différente de la nôtre. (RdDM 1855: 747) 
Trzeba zestawić ten cytat $\mathrm{z}$ artykułu opublikowanego przez Renana w Revue des Deux Mondes (1855) z następującymi wersami z Rzeczy o wolności stowa oraz z kolejną notatką z mitologii:

Żaden lud nigdy - nigdzie - i nie miał, i nie ma

Takiej pieśni jak Psalmy! Każda przy niej niema. (Norwid, Pisma 3: 581)

Poezja najwyższą człowieczą funkcją cywilizacyjną, muzyka częścią jej.

Ale Ramajana i Mahabharata cóż do Psalmów!... (Świeć się Imię Twoje).

(Pisma 7: 255, Notatki z mitologii 96)

Obiektywnym miernikiem wysokiej rangi duchowej i estetycznej Psalmów okazuje się zarówno u Norwida, jak i Renana ich uniwersalność. Dowodem owej uniwersalności jest to, że zawarte w nich doświadczenia i nastroje oddziałują na czytelników mówiących wieloma językami, należącymi do różnych grup językowych. W przekładzie nie tracą niczego ze swojej pierwotnej siły, którą jednak zawdzięczają semickiemu geniuszowi religijnemu. Z punktu widzenia Norwida i Renana poezja Psalmów jest wciąż żywa, podczas gdy pomniki literatury w sanskrycie, owym narzeczu przypuszczalnie najbliższym pierwotnemu językowi indoeuropejskiemu, są raczej szacownym reliktem dawnych, na zawsze minionych czasów. Ową uniwersalność Psalmy dzielą $\mathrm{z}$ arcydziełami literatury greckiej, która - w odróżnieniu od twórczości Indów - zachowała (zdaniem zarówno Renana, jak i Norwida) swą żywotność również dla współczesnego człowieka ${ }^{23}$ :

Israël eut, comme la Grèce, le don de dégager parfaitement son idée, de l'exprimer dans un cadre réduit et achevé. La proportion, la mesure, le goût, furent en Orient le privilège exclusif du peuple hébreu, et c'est par là qu'il réussit à donner à la pensée et aux sentiments une forme générale et acceptable pour tout le genre humain. (RdDM 1855: 747)

Okazuje się więc, że uniwersalna idea ludzkości (jej wcieleniem u Norwida jest Chrystus, Renan kojarzy ją zaś z „chrześcijaństwem wolnym, zróżnicowanym $\mathrm{i}$ indywidualistycznym, przekraczającym granice organizacyjne kościołów"24)

\footnotetext{
${ }^{23} \mathrm{~W}$ kolejnej notatce $\mathrm{z}$ mitologii Norwid jeszcze znacznie silniej niż Renan eksponuje wyłączność geniusza żydowskiego pod tym względem, przypisując tę uniwersalność uprzywilejowanej relacji narodu wybranego z Bogiem: „281. (Tymczasem jeden lud Boga jedynego świadczy i świat dowolnym dziełem Jego)" (Pisma 7: 293).

${ }^{24}$ E. Renan, L'avenir religieux des sociétés modernes, RdDM 1860: 791.
} 
nie wywodzi się z początków (wspólnych czy też oddzielonych od siebie) ludzkich ras (i języków), lecz jest celem, które ludy i narody urzeczywistniają drogą wzajemnego przenikania się. Każde plemię wnosi do tej postępującej wspólnoty ludzkiej swój własny, jemu tylko wrodzony talent. Taki punkt widzenia na dzieje ludzkości wyraził Norwid w słynnym wierszu Moja ojczyzna, napisanym w Paryżu, w roku 1861:

Ojczyzna moja nie stąd wstawa czołem;

Ja ciałem zza Eufratu,

A duchem sponad Chaosu się wziąłem:

Czynsz płacę światu.

Naród mię żaden nie zbawił ni stworzył;

Wieczność pamiętam przed wiekiem;

Klucz dawidowy usta mi otworzył,

Rzym nazwał człekiem. (Pisma 1: 336)

Późniejsze zainteresowania językoznawcze, mitologiczne i etnograficzne znacznie jeszcze wzbogaciły ową specyficznie Norwidowską odmianę uniwersalizmu cywilizacyjnego, stanowiącego „principium” europejskości, ponad podziałami na rasy i grupy językowe.

BIBLIOGRAFIA

\section{LITERATURA}

Biela, Bogusław. „Czy Norwid współpracował z Hyacinthe de Charency przy pisaniu Syna Panny?”. Studia Norwidiana 27-28, 2009-2010, ss. 149-183.

Burnouf, Eugène. Introduction à l'histoire du Buddhisme Indien. Imprimerie Royale, 1854.

Burnouf, Émile. La science des religions. Paris, 1872.

Duchiński, Franciszek. Peuples Aryâs et Tourans. Agriculteurs et Nomades. Nécessité des reformes dans l'exposition de l'histoire des peuples Aryâs-Européens \& Tourans. Particulièrement des Slaves et des Moscovites. Friedrich Klincksieck, 1864.

Dupront, Alphonse. P. D. Huet et l'exégèse comparatiste au XVII siècle. E. Leroux, 1930.

Głowiński, Michał. „Norwida wiersze-przypowieści”. Cyprian Norwid. W 150-lecie urodzin, red. Maria Żmigrodzka, Państwowy Instytut Wydawniczy, 1973, ss. 72-109.

Grzędzielska, Maria. „Nie nawiązane ogniwo poezji polskiej”. Cyprian Norwid. W 150-lecie urodzin, red. Maria Żmigrodzka, Państwowy Instytut Wydawniczy, 1973, ss. 124-150.

Junkiert, Maciej. Grecja i jej historia w twórczości Cypriana Norwida. Wydawnictwo Naukowe UAM, 2012.

Kalendarz życia i twórczości Cypriana Norwida, t. 1-3, oprac. Zofia Trojanowicz, Elżbieta Lijewska, Wydawnictwo Poznańskie, 2007. 
Lenormant, François. Manuel de l'histore ancienne de l'Orient jusqu'aux guerres médiques, t. 1. A. Levy Fils, 1868.

Müller, Max. La science du langage [LSdL]. Cours professée à l'Institut Royale de la GrandeBretagne en l'année 1861 par M. Max Müller [...]. Deuxième édition, revue et augmentée sur le cinquième édition anglaise, Paris, 1867.

Norwid, Cyprian. Pisma wszystkie, t. 1-11, oprac. Juliusz W. Gomulicki, Państwowy Instytut Wydawniczy, 1971.

Norwid, Cyprian. Dzieła zebrane, t. 1-2, oprac. Juliusz W. Gomulicki, Państwowy Instytut Wydawniczy, 1966.

Ott, Auguste. Manuel de l'histoire universelle. Chez Paulin, Libraire, 1844.

Pniewski, Dariusz. Między obrazem i słowem. Studia o poglądach estetycznych i twórczości Norwida. Towarzystwo Naukowe KUL, 2005.

Rzońca, Wiesław. Premodernizm Norwida - na tle symbolizmu literackiego drugiej połowy XIX wieku. Wydział Polonistyki Uniwersytetu Warszawskiego, 2013.

Śniedziewski, Piotr. Mallarmé - Norwid. Milczenie i poetycki modernizm we Francji oraz w Polsce. Uniwersytet im. Adama Mickiewicza w Poznaniu, 2008.

Żmigrodzka, Maria, red. Cyprian Norwid w 150-lecie urodzin. Państwowy Instytut Wydawniczy, 1973.

\section{OPRACOWANIA ENCYKLOPEDYCZNE WYDANE PRZEZ L'ABBÉ MIGNE}

Demonstrations évangéliques [...] tome cinquième, contenant les demonstrations de Huet et de Clarke [DE], Petit-Montrouge [...] hors la barrière d'enfer de Paris, 1843.

Dictionnaire universel de mythologie ancienne et moderne [...], Paris, 1855.

Dictionnaire historique, archéologique, philologique, chornologique, géographique et littéral de la Bible par le révérend Père Dom Augustin Calmet, religieux Bénédictin, abbé de Senon, quatrième édition, revue, corrigée, complétée et actualisée par M. l'abbé A.F. James [...] publié par M. l'abbé Migne, t. 2, Paris, 1859.

\section{CZASOPISMA}

Revue des Deux Mondes [RdDM]:

Vol. 2, No. 4, 15 Mai 1853

Vol. 12, No. 4, 15 Novembre 1855

Vol. 29, No. 4, 15 Octobre 1860

Vol. 47, No. 4, 15 Octobre 1863

Vol. 54, No. 4, 15 Décembre 1864

Vol. 57, No. 3, 1er Juin 1865

Vol. 76, No. 1, 1er Juillet 1868.

Studia Norwidiana, t. 27-28, 2009-2010. 


\title{
NORWID, KOLEBKA ARIÓW \\ A EUROPA JAKO WIELOKULTUROWE „PRINCIPIUM”
}

\author{
Streszczenie
}

W czasie swej emigracji w Paryżu Cyprian K. Norwid bardzo się interesował współczesną mu mitologią porównawczą, a także językoznawstwem historycznym, które również stosował jako metodę komparatystyczną. Artykuł próbuje ustalić źrodła jego własnych spekulacji mitologicznych i lingwistycznych. Okazuje się, że znane mu były zarówno ówczesne autorytety w tym zakresie (np. Ernest Renan, Max Müller, którzy posługiwali się metodologią pozytywistyczną), jak i zbiorowe opracowania encyklopedyczne wydane przez katolickiego duchownego, ojca J.P. Migne, które próbowały uzgodnić odkrycia nauki pozytywistycznej z tradycją chrześcijańską. Norwid zaczerpnął swą wiedzę z obu źródeł, choć perspektywa katolickich dykcjonarzy była mu bliższa (nie akceptował jednak bezkrytycznie wszystkich ich ustaleń). „Archaiczne” (z punktu widzenia nauki pozytywistycznej) korzenie jego spekulacji mitologicznych i językoznawczych broniły go jednak przed pokusą ulegania (pseudo)naukowemu dyskursowi rasowemu. Jego chrześcijański uniwersalizm spotyka się tu $\mathrm{z}$ agnostycznym uniwersalizmem Renana. W obu przypadkach istotnym elementem owego uniwersalizmu było podkreślanie ponadnarodowej wartości tradycji związanych ze Starym Testamentem i judaizmem.

Słowa kluczowe: Norwid; Renan; mitologia porównawcza; językoznawstwo historyczne; rasa

\section{NORWID, THE CRADLE OF THE ARYANS \\ AND EUROPE AS A MULTICULTURAL "PRINCIPIUM"}

S u m m a ry

Norwid, who lived in exile in Paris, took a great interest in comparative mythology and historical linguistics, using a similar methodology for both. This article attempts to establish the sources of his own mythological and linguistic speculations. It turns out that he knew both the writings of the acknowledged authorities in this field who used a positivist methodology, and the Catholic dictionaries published by the Abbé Migne which aimed at reconciling the discoveries of positivist science with the Christian tradition. Norwid's knowledge derived from both sources, although he felt a greater closeness to the perspective of the Catholic dictionaries (even though he did not blindly accept all their findings). The "archaic" (from a positivist perspective) roots of his mythological and linguistic speculation defended him, however, against the temptation to give in to a [pseudo-]scientific racial discourse. Here, his Christian universalism goes hand-in-hand with Renan's agnostic universalism. The essential element of this universalism derived, in both cases, from an emphasis on the supranational value of traditions linked with the Old Testament and Judaism.

Keywords: Norwid; Renan; comparative mythology; historical linguistics; race 